\title{
De Novo Asymmetric Synthesis of D- and L-Swainsonine
}

\author{
Haibing Guo and George A. O'Doherty ${ }^{*}$ \\ Department of Chemistry, West Virginia University, Morgantown, WV 26506
}

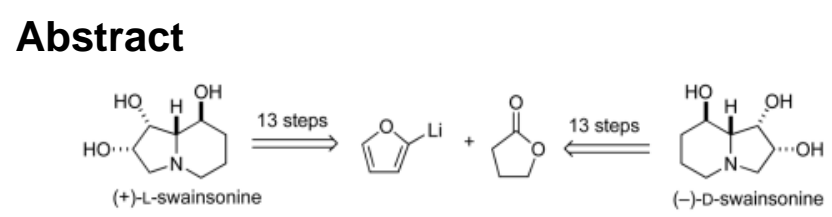

The enantioselective syntheses of both enantiomers of the indolizidine natural product swainsonine have been achieved in 13 steps from furan. The indolizidine ring system is installed by a one-pot hydrogenolysis of both an azide and O-Bn group along with an intramolecular reductive amination reaction. The asymmetry of swainsonine was introduced by Noyori reduction of an acylfuran. This route relies upon an Achmatowicz rearrangement, a diastereoselective palladium catalyzed glycosylation, Luche reduction and a dihydroxylation reaction.

Over the years the indolizidine class of alkaloid natural products has attracted a lot of attention from the synthetic community because of their interesting structures and potent biological activities. ${ }^{1}$ A unique subset of the indolizidine natural products is noteworthy because of their ability to serve as potent glycosidase inhibitors and as such they have received attention from both the synthetic and carbohydrate communities. ${ }^{2}$ The potent mannosidase inhibitor, swainsonine 1 has probably received most of this attention. ${ }^{3}$

Since the first syntheses by Richardson, ${ }^{4}$ Fleet, ${ }^{5}$ Suami $^{6}$ and Sharpless ${ }^{7}$ in 1984 , there have been over 30 syntheses of swainsonine. Most routes to swainsonine draw theirasymmetry from carbohydrate starting materials (e.g. Richardson and Fleet). Of the syntheses, the routes by $\mathrm{Cha}^{8}$ and Pearson ${ }^{9,3 \mathrm{f}}$ are most practical. Cha's route is considered the shortest (8 steps from D-erythrose), whereas, the 15-step synthesis of swainsonine by Pearson provided material on a multigram scale. Key to the success of the Pearson synthesis is the use of highly diastereoselective transformations.

In 1995, Hirama was the first to prepare the enantiomerof swainsonine (ent)-1. ${ }^{10}$ Hirama synthesized L-swainsonine in 20 steps from butyrolactone. ${ }^{10 \mathrm{a}} \mathrm{A}$ year later, Fleet synthesized L-swainsonine for its evaluation as a glycosidase inhibitor. ${ }^{10 \mathrm{~b}}$ Fleet's study of L-swainsonine showed that it is a potent inhibitor of naringinase, an L-rhamnosidase enzyme. That is to say, a protonated L-swainsonine (ent)-2 functions as a transition state mimic for the enzymatic hydrolysis of both L- $\alpha$-mannose (ent)-3 and L-rhamnose (ent)-4 (Figure 1). ${ }^{10}$ Typically the naturally occurring mannose exists in its D-form and the naturally occurring 6-deoxy-mannose, rhamnose, exist in its L-form.

As a continuation of our efforts aimed at the de novo synthesis of oligosaccharides, we wanted to prepare swainsonine-containing manno-oligosaccharides. The goal of these efforts is to develop more selective glycosylation inhibitor, with the hope that it would display better antitumor and antiviral activity than swainsonine. ${ }^{11}$ Thus, we became interested in a practical 
synthesis of swainsonine. In particular, we desired a route that was shorter and as practical as the Pearson approach. Since we wanted access to both the D- and L-swainsonine, we planned to synthesize swainsonine by a de novo route.

Retrosynthetically, we envisioned that we could establish the D/L stereochemistry by a Noyori reduction of acylfuran10, which can be prepared in one step from furan and $\gamma$-butyrolactone. An Achmatowicz reaction should convert the furyl alcohol 9 into a $C$-6 substituted pyranone 8. ${ }^{12}$ A stereoselective protection of the anomeric alcohol followed by ketone reduction and a palladium catalyzed allylic substitution should convert 8 into 7 . With the $C-1,4,5$ stereochemistry established in $\mathbf{7}$ a diastereoselective dihydroxylation reaction should install the manno-stereochemistry in $\mathbf{6}$.

Finally, we planned on a global hydrogenolysis/alkylation/reductive amination sequence to convert azidosugar 6 into swainsonine 1 via imine 5. This one-pot transformation would initially involve an azide reduction to form the aminosugar 13, which after an intramolecular alkylation would undergo hydrogenolysis to free up the anomeric hydroxyl group to form 14. Finally, under the same reaction conditions 14 should undergo a reductive amination reaction to form swainsonine. ${ }^{13}$ Herein we describe our successful efforts to implement this strategy for the de novo synthesis of swainsonine.

As outlined in Scheme 3, our approach to both D- and L-swainsonine began with commercially available furan and $\gamma$-butyrolactone 12. ${ }^{14}$ Treatment of $\gamma$-butyrolactone 12 with a THF solution of 2-lithiofuran 11 gave furyl ketone $\mathbf{1 6}$ in good yield (74\%). The primary alcohol of $\mathbf{1 6}$ was protected as a TBS-ether using TBSCl/imid. in DMF providing 10 in an excellent yield (98\%). The asymmetric reduction of acylfuran 10 under modified Noyori conditions 15 afforded the desired furyl alcohol (ent)-9 in 89\% yield with high enantiomeric purity (> 96\% ee). Exposing furyl alcohol (ent)-9 to the typical Achmatowicz conditions ( $\mathrm{NBS}$ inTHF/ $\mathrm{H}_{2} \mathrm{O}$ ) gave the ringexpanded product pyranone (ent)-8in good yield (84\%).

In order to diastereoselectively protect the anomeric position as benzyl ether; we employed a two-step acylation/Pd-catalyzed glycosylation (Scheme 4). Diastereoselective acylation of hemiacetal (ent)-8 with(Boc) ${ }_{2} \mathrm{O}$ provided the Boc-protected pyranone 17 (8:1 $\alpha / \beta$ ratio) in excellent yield (85\%). Coupling of pyranone 17 with benzyl alcohol in presence of $2.5 \%$ palladium(0) and 5\% triphenylphosphine gave Bn-protected pyranone $\mathbf{1 8}$ as a single diastereomer in excellent yield $(88 \%) .12 \mathrm{~b}, 16$

With pyranone 18 suitably protected at the anomeric position, we next investigated the stereoselective azide incorporation at $C-4$ using palladium catalysis (Scheme 5 ). The $C-4$ ketone in 18 was diastereoselectively reducedwith $\mathrm{NaBH}_{4}\left(\mathrm{CH}_{2} \mathrm{Cl}_{2} / \mathrm{MeOH},-78{ }^{\circ} \mathrm{C}\right)$ forming theequatorial allylic alcohol 19 in excellent yield (94\%). In order to convert the allylic alcohol of 19 into a better leaving group it was acylated with methyl chloroformate to form the mixed carbonate $20(72 \%)$. Exposing carbonate 20 to the conditions developed by Sinou 17

$\left(\mathrm{TMSN}_{3},(\mathrm{Pd}(\text { allyl }) \mathrm{Cl})_{2} / 1,4\right.$-bis(diphenylphosphino)butane) affordeda single regio- and stereoisomeric allylic azide (ent)-7 in a good yield (77\%). ${ }^{18}$

Before the one-pot reductive cyclization could be attempted the TBS-protected primary alcohol needed to be converted into a good leaving group and the $C-2 / C-3$ diol needed to be introduced (Scheme 6). Deprotection of TBS-ether (ent)-7 with a THF solution of TBAF gave the primary alcohol $\mathbf{2 1}$ in near quantitative yield (99\%). The primary alcohol in $\mathbf{2 1}$ was converted to a mesylate $\left(\mathrm{MeSO}_{2} \mathrm{Cl}, \mathrm{Et}_{3} \mathrm{~N}, 0{ }^{\circ} \mathrm{C}\right)$, forming 22 in similarly excellentyield (99\%). The mannostereochemistry in diol (ent)-6 was stereoselectively installed by dihydroxylation of allylic azide 22 under Upjohn conditions $\left(\mathrm{OsO}_{4} / \mathrm{NMO}, 93 \%\right) .{ }^{19}$ Finally, L-swainsonine (ent)-1 was obtained by exhaustive hydrogenation of an ethanol solution of $\operatorname{diol}($ ent $)-6$ with $\mathrm{Pd}(\mathrm{OH})_{2} / \mathrm{C}$ in excellent yield $88 \%$ (100 psi, 3days). ${ }^{20}$ 
Similarly, a protected form of L-Swainsonine 29 could also be synthesized from (ent)-7 by incorporating an acetonide protection (Scheme 7). Once again a stereoselective dihydroxylation of allylic azide (ent)-7 wasperformed ( $\left.\mathrm{OsO}_{4} / \mathrm{NMO}\right)$ yielding diol $\mathbf{2 4}(92 \%)$. Protectingdiol 24 with 2,2-dimethoxypropane and acid catalyst $p$-TsOH, afforded acetonide 25 (97\%), whose TBS group was deprotected (TBAF) to provide primary alcohol 26. Mesylation of $\mathbf{2 6}\left(\mathrm{MeSO}_{2} \mathrm{Cl}, \mathrm{Et}_{3} \mathrm{~N}, 0{ }^{\circ} \mathrm{C}\right)$ gave mesylate 28in excellent yield (99\%). Once again, exhaustive hydrogenation/hydrogenolysis of a THF/ethanol solution of azide $\mathbf{2 8}$ (100 psi, 4 days) afforded the protected swainsonine $\mathbf{2 9}$, which was easily deprotected (95\%) to give L-swainsonine (ent)-1. This alternative sequence gave L-swainsonine (ent)-1 in similarly excellent overall yield (70\% from allylic azide (ent) -7 in 6 steps) ${ }^{20}$ Swainsonine prepared by either of these two methods provided material with physical and spectral data (melting point, ${ }_{3-10}^{1} \mathrm{H}$ NMR, ${ }^{13} \mathrm{C}$ NMR, IR, and optical rotation), which matched that of the natural material.

In conclusion, two short de novo asymmetric syntheses of swainsonine (1) and its enantiomer (ent)-1 have been developed. This highly enantio- and diastereocontrolled route illustrates the utility of the Noyori reduction, Achmatowicz reaction and a palladium catalyzed glycosylation for natural product synthesis. This approach provided both enantiomers of swainsonine in 17\% overall yields from furan 11, respectively. It is also worth noting that this route provided swainsonine in comparable efficiency to the previous carbohydrate based approach; ${ }^{3-10}$ however, this de novo approach started from achiral sources and required the use of only two protecting groups. Further application of this approach to the synthesis of swainsonine containing oligosaccharides and biological testing is ongoing.

\section{Supplementary Material}

Refer to Web version on PubMed Central for supplementary material.

\section{Acknowledgements}

We are grateful to NIH (GM63150) and NSF (CHE-0415469) for the support of our research program and NSFEPSCoR (0314742) for a $600 \mathrm{MHz}$ NMR at WVU.

\section{References}

1. (a) Asano N, Nash RJ, Molyneux RJ, Fleet GWJ. Tetrahedron: Asymmetry 2000;11:1645-1680. (b) Michael JP. Nat Prod Rep 1997;14:619-636. [PubMed: 9418297]

2. For a review of iminosugars: (a) Sears P, Wong CH. Angew Chem, Int Ed 1999;38:2300-2324. (b) Tyler PC, Winchester BG. Iminosugars as Glycosidase Inhibitors 1999:125-156. (c) Burgess K, Henderson I. Tetrahedron 1992;48:4045-66. (d) Fellows LE, Kite GC, Nash RJ, Simmonds MSJ, Scofield AM. Rec Adv Phytochem 1989;23:395-427.

3. For a review of swainsonine syntheses, see: (a) Nemr AE. Tetrahedron 2000;56:8579-8629. For more recent syntheses, see: (b) Martin R, Murruzzu C, Pericas MA, Riera A. J Org Chem 2005;70:23252328. [PubMed: 15760222] (c) Heimgaertner G, Raatz D, Reiser O. Tetrahedron 2005;61:643-655. (d) Song L, Duesler EN, Mariano PS. J Org Chem 2004;69:7284-7293. [PubMed: 15471482] (e) Lindsay KB, Pyne SG. Aus J Chem 2004;57:669-672. (f) Pearson WH, Ren Y, Powers JD. Heterocycles 2002;58:421-430. (g) Lindsay KB, Pyne SG. J Org Chem 2002;67:7774-7780. [PubMed: 12398502] (h) Buschmann N, Rueckert A, Blechert S. J Org Chem 2002;67:4325-4329. [PubMed: 12054970] (i) Zhao H, Hans S, Cheng X, Mootoo DR. J Org Chem 2001;66:1761-1767. [PubMed: 11262124]

4. Ali MH, Hough L, Richardson AC. J Chem Soc, Chem Commun 1984:447-448.

5. Fleet GWJ, Gough MJ, Smith PW. Tetrahedron Lett 1984;25:1853-1856.

6. Suami T, Tadano K, Iimura Y. Chem Lett 1984:513-516.

7. Adams CE, Walker FJ, Sharpless KB. J Org Chem 1985;50:420-422. 
8. Bennett RB, Choi JR, Montgomery WD, Cha JK. J Am Chem Soc 1989;111:2580-2582.

9. Pearson WH, Hembre EJ. J Org Chem 1996;61:7217-7221. [PubMed: 11667634]

10. (a) Oishi T, Iwakuma T, Hirama M, Ito S. Synlett 1995:404-406. (b) Davis B, Bell AA, Nash RJ, Watson AA, Griffiths RC, Jones MG, Smith C, Fleet GWJ. Tetrahedron Lett 1996;37:8565-8568.

11. For the bioactivities of swainsonine, see: (a) Elbein AD. FASEB J 1991;5:3055-3063. [PubMed: 1743438] (b) Goss PE, Reid CL, Bailey D, Dennis JW. Clin Cancer Res 1997;3:1077-1086. [PubMed: 9815786] (c) Galustian C, Foulds S, Dye JF, Guillou PJ. Immunopharmacol 1994;27:165172. (d) Grzegorzewski K, Newton SA, Akiyama SK, Sharrow S, Olden K, White SL. Cancer Commun 1989;1:373-279. [PubMed: 2484638] (e) Elbein AD. Annu Rev Biochem 1987;56:497534. [PubMed: 3304143] (f) Cenci Di Bello I, Fleet G, Namgoong SK, Tadano K, Winchester B. Biochem J 1989;259:855-861. [PubMed: 2499316] (g) Winchester B, Fleet GWJ. Glycobiology 1992;2:199-210. [PubMed: 1498417] (h) Tulsiani DRP, Harris TM, Touster O. J Biol Chem 1982;257:7936-7939. [PubMed: 6806288] (i) Kino T, Inamura N, Nakahara K, Kiyoto S, Goto T, Terano H, Kohsaka MJ. Antibiot 1985;38:936-940.

12. An Achmatowicz reaction is the oxidative rearrangement of furyl alcohols to 2-substituted 6hydroxy-2H-pyran-3(6H)-ones, see: (a) Achmatowicz O, Bielski R. Carbohydr Res 1977;55:165176. [PubMed: 861975]For its recent use in carbohydrate synthesis see: (b) Guo H, O'Doherty GA. Org Lett 2005;7:3921-3924. [PubMed: 16119932] and references therein

13. In the Fleet synthesis of swainsonine a similar reductive amination was employed, see Ref. 5.

14. While we have prepared both D and L-swainsonine, for simplicity herein we only show the Lenantiomer.

15. Previously, we have shown that a lower ratio of $\mathrm{HCO}_{2} \mathrm{H} / \mathrm{Et}_{3} \mathrm{~N}(1: 1$ instead of 2:1) was required for the Noyori reduction of compounds with primary TBS-groups, see: Li M, Scott JG, O'Doherty GA. Tetrahedron Lett 2004;45:1005-1009.

16. (a) Babu RS, O’Doherty GA. J Am Chem Soc 2003;125:12406-12407. [PubMed: 14531673] (b) Babu RS, Zhou M, O’Doherty GA. J Am Chem Soc 2004;126:3428-3429. [PubMed: 15025462] (c) Babu RS, O’Doherty GA. J Carbohydr Chem 2005;24:169-177.

17. de Oliveira RN, Cottier L, Sinou D, Srivastava RM. Tetrahedron 2005;61:8271-8281.

18. Presumably, because of the rigid nature of the 7 and the equatorial nature of the allylic azide no $[3,3]$ sigmatropic rearrangement was observed, see: Feldman AK, Colasson B, Sharpless KB, Fokin VV. J Am Chem Soc 2005;127:13444-13445. [PubMed: 16190677]

19. (a) Hudlicky T, Abboud KA, Bolonick J, Maurya R, Stanton ML, Thorpe AJ. Chem Commun 1996:1717-1718. (b) Takao KI, Hara M, Tsujita T, Yoshida KI, Tadano KI. Tetrahedron Lett 2001;42:4665-4668.

20. By simply switching the $(S, S)$-Noyori reagent for the reduction of 10 to (ent)-9 to the $(R, R)$-Noyori reagent (10 to 9), D-swainsonine was prepared from 9 in nearly identical overall yield.

Org Lett. Author manuscript; available in PMC 2008 September 7. 


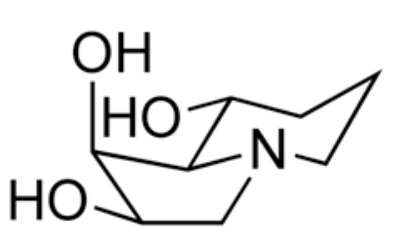

D-swainsonine 1

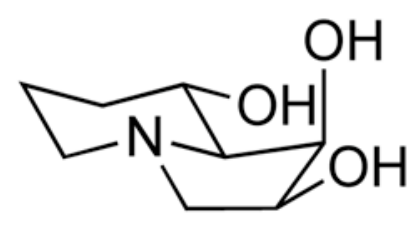

L-swainsonine (ent)-1

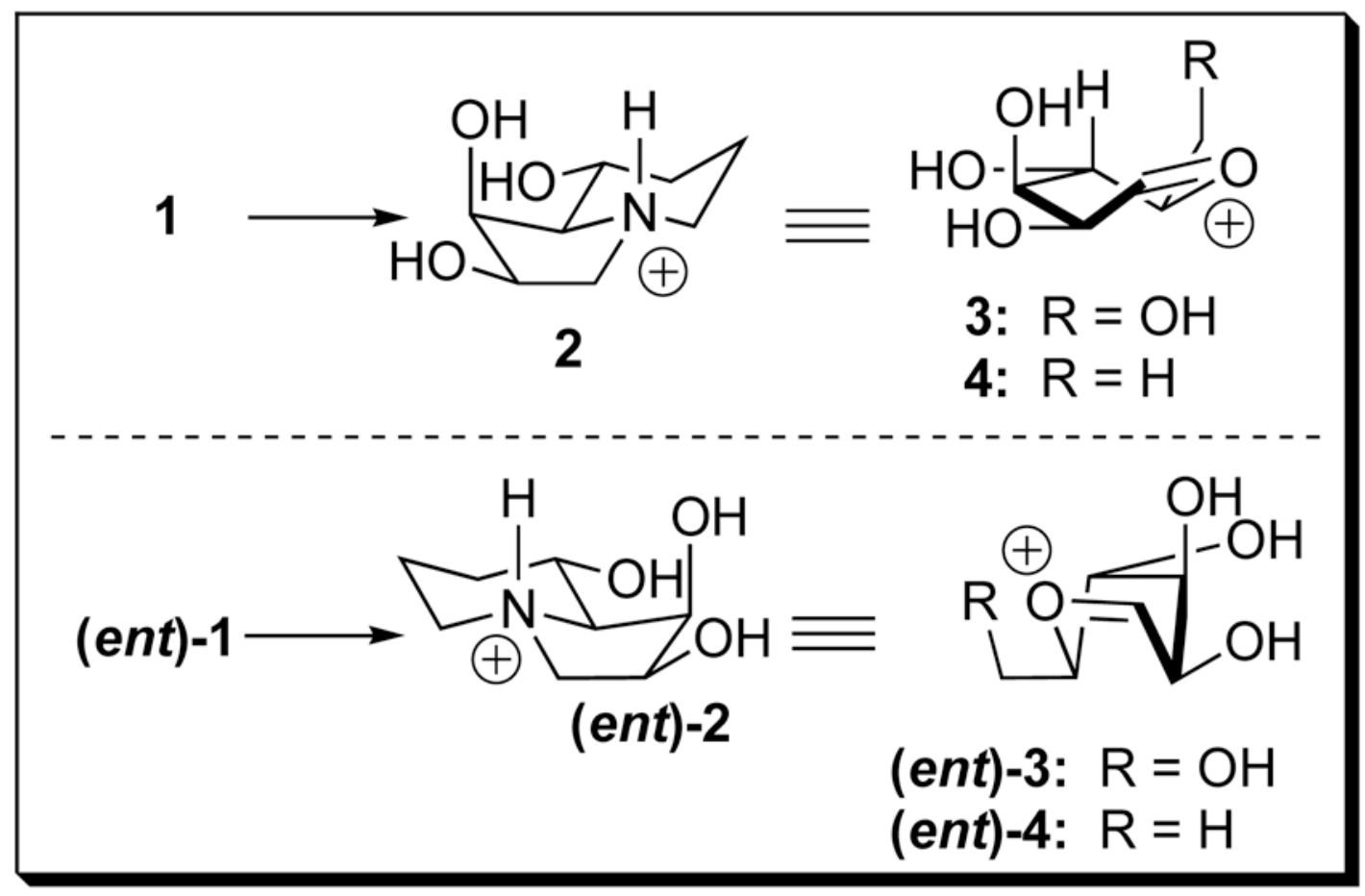

Figure 1.

Swainsonine (1) and L-enantiomer (ent-1) 
<smiles>OC1CN2CCC(C1O)C(O)C2O</smiles><smiles>C=C</smiles><smiles>OC1C2CCCNC(O2)C(O)C1O</smiles><smiles>C=C</smiles>

D-swainsonine 1

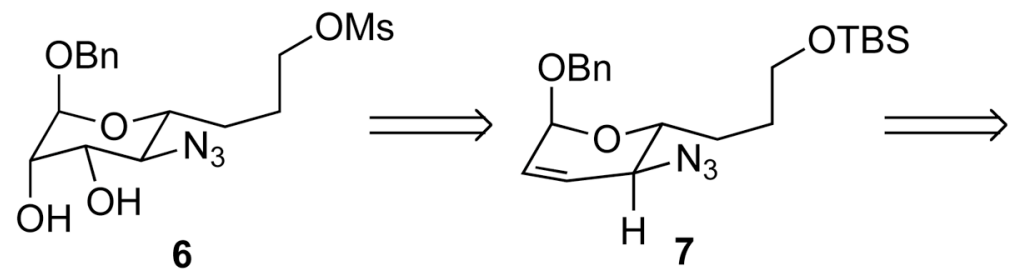<smiles>C=C=C[Se-]OCCC[C@@H](O)c1ccco1</smiles><smiles>C#C[Sb](=O)OCCCC(=O)c1ccco1</smiles>

10<smiles>O=C1CCCO1</smiles>

11

12

Scheme 1.

Retrosynthetic analysis of swainsonine (1) 

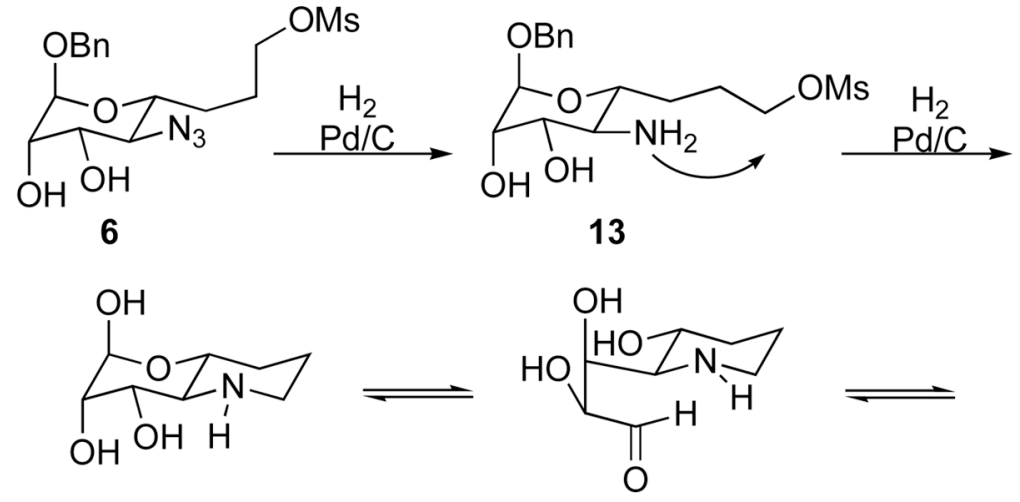

5

14
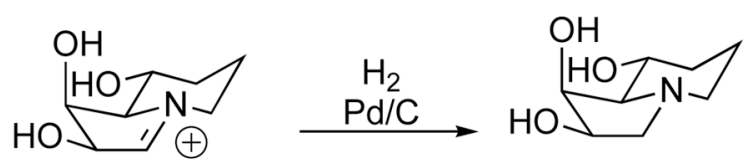

15

D-swainsonine

1

Scheme 2.

Key reductive cyclization to swainsonine (1) 
<smiles>[AlH2]c1ccco1</smiles>
11<smiles>O=C1CCCO1</smiles>

12

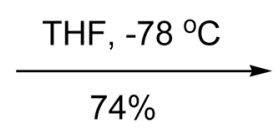
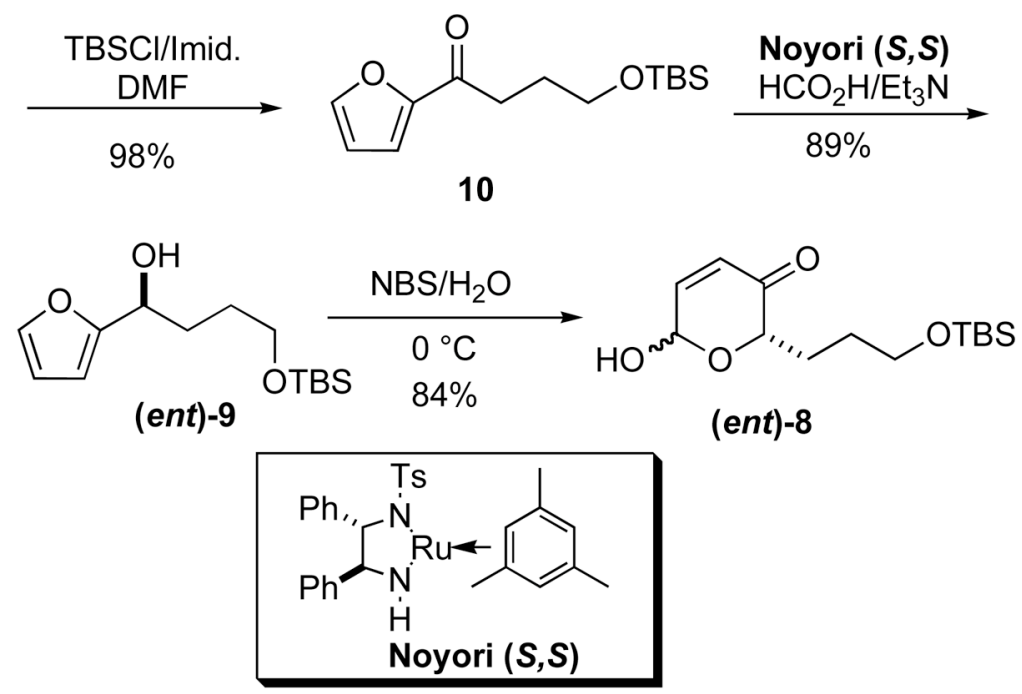

Scheme 3.

Enantioselective synthesis of pyranone (ent)-8 


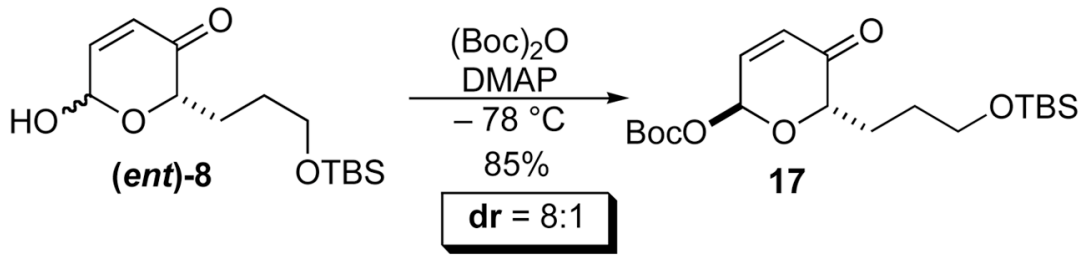<smiles>[3H][R5](=O)(O)OCCC[C@H]1OC(OC(C)(C)C)C=CC1=O</smiles>

Scheme 4.

Palladium catalyzed $C-1$ protection 
<smiles>CCCCCCC[C@H]1OC(OCc2ccccc2)C=CC1=O</smiles>

$\mathrm{CH}_{3} \mathrm{OCOCl}$

$19 \underset{72 \%}{\stackrel{\text { DMAP/Pyridine }}{\longrightarrow}} 20$

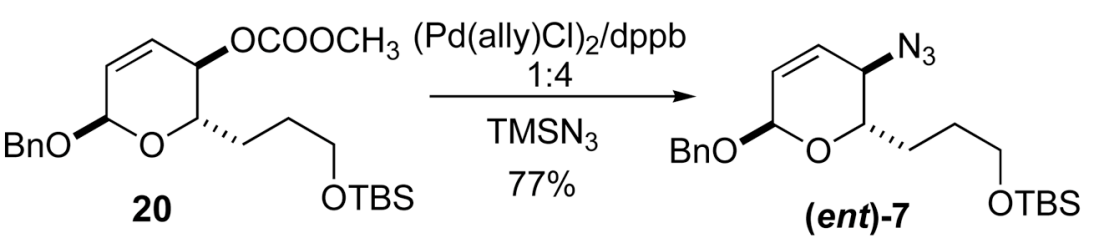

Scheme 5.

Palladium catalyzed $C$-4 azide incorporation 


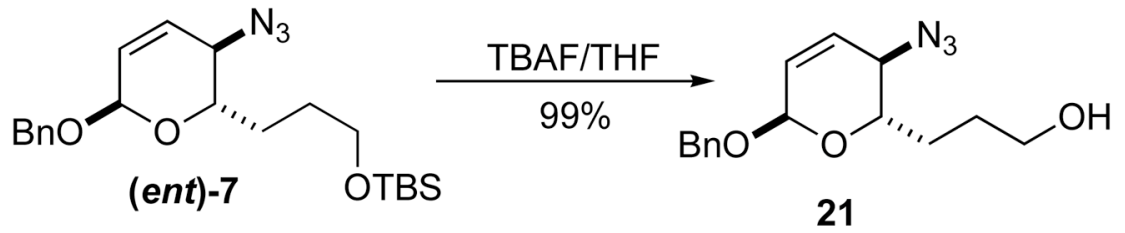<smiles>CCN(CC)CCOC1C=CC([N])C(CCCOC)O1</smiles>

22<smiles>COCCC[C@H]1OC(OCc2ccccc2)[C@H](O)[C@@H](O)C1N</smiles><smiles>OC1CN2CCC[C@H](O)C2C1O</smiles>

(+)-L-Swainsonine

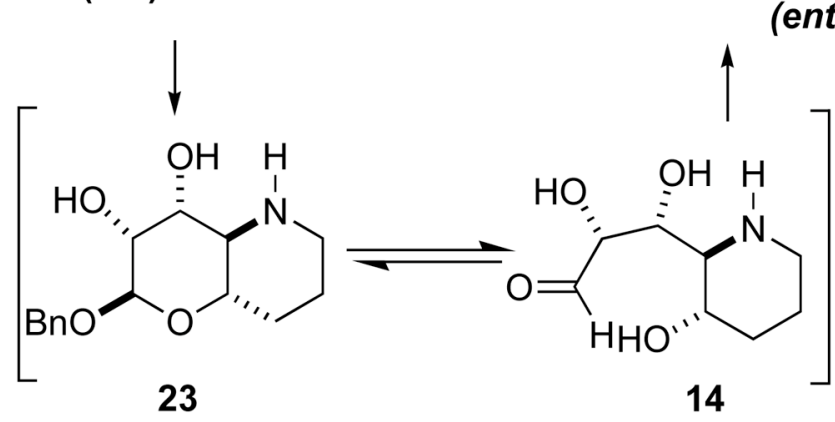

Scheme 6.

Diastereoselective $C-2 / 3$ dihydroxylation and reductive cyclization to L-swainsonine (ent-1) 
<smiles>C[Sb](C)(C)OCCC[C@H]1OC(OCc2ccccc2)C=CC1N</smiles>
(ent)-7

24<smiles>COC(C)(C)O[B-](C)([O-])O</smiles>

25<smiles>CC1(C)O[C@H]2C(O)O[C@H](CCCO)C(N)[C@H]2O1</smiles>

26

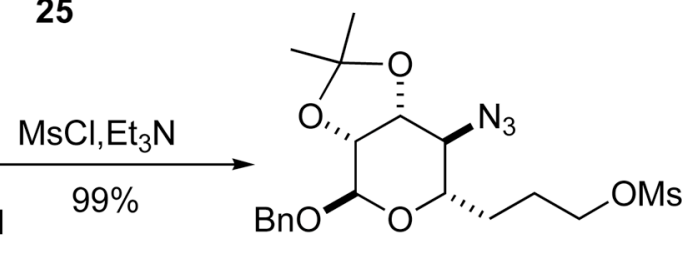

28

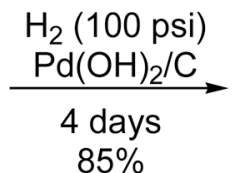

$85 \%$<smiles>CC1(C)OC2CN3CCC[C@H](O)[C@H]3C2O1</smiles>

29<smiles>OC1CN2CCC[C@H](O)[C@@H]2C1O</smiles>

(+)-L-Swainsonine (ent)-1

Scheme 7.

Synthesis of swainsonine (ent)-1 via a protected swainsonine (29) 